Margarita Boiko, Doctor of Economics, Professor, Kyiv National University of Trade and Economics, Kyiv Ukraine, ORCID: 0000-0003-0249-1432; ResearcherID: N-3073-2016

Nadiia Vedmid, Doctor of Economics, Professor, Kyiv National University of Trade and Economics,

Kyiv Ukraine, ORCID: 0000-0002-5010-6394

ResearcherID: N-2889-2016

Liudmyla Romanchuk, Lecturer, Kyiv National University of Trade and Economics, Kyiv Ukraine, ORCID: 0000-0002-2505-6743

ResearcherID: N-2860-2016

\title{
VALUE OF RELATIONSHIP MARKETING IN HOSPITALITY
}

The article discusses relationship marketing concept which becomes the dominant marketing paradigm and subject of many marketing researches. Relationship marketing becomes more popular in many marketing areas such as service marketing, marketing research, customer behaviour, international marketing, strategic marketing, direct marketing etc. Applying relationship marketing in service sector is presented. The authors elaborate on the opinion that client's satisfaction and loyalty to the company for long time., as a major trend in the process of transformation of social development, has led not only to development of new business models and offering non-standard solutions. The authors substantiate a scientific position on understanding the benefits of relationship marketing including a high return on investment, getting great reviews, getting an honest perspective on business decisions, improving returns on campaigns. The article presents the market model helps the organization to study about the stakeholders and key market domain that may be important to them.

Keywords: relationship marketing, marketing concept, service sector, hospitality, customer satisfaction. 


\section{Relevance of research topic.}

During the 21 st century the business sector has been becoming more complex in both domestic and global markets than it used to be largely due to the increasingly intense competition, saturated markets and the strong trend of globalization. The level of uncertainty in the business environment has compelled business firms to restructure themselves and thus increase their chances of survival and growth.

Companies all over the world are doing everything possible to save their customers. To be the leader in the modern market, companies must focus on the consumer - to provide their target customers with the highest value. Most markets are already quite stable, and not so many new ones are client oriented. Competition is increasing, and the cost of attracting new consumers is growing. In addition, consumers are becoming more independent and demanding. To stay competitive, a modern company must be knowledgeable about its consumers. To do this, new business models are developed and non-standard solutions are offered.

Attracting new customers is usually more expensive than re-selling to an existing customer. Moreover, if the client was dissatisfied, then his conquest cost the company six times more expensive. In addition, researchers A. Reicholdand, M. Sasser proved that if a company reduces the level of consumer outflows by at least $5 \%$, then as a result, it will be able to increase its profit by $25-85 \%$. Therefore, a critical factor for modern business is the marketing of relationships with consumers.

Relationship marketing concept has become the dominant marketing paradigm and subject of many marketing researches. Applying relationship marketing in service sector means that client is satisfied and loyal to the company for long time.

\section{Formulation of the problem.}

Relationship marketing demands the improvement of internal operations in hospitality. Often customers do not return a hotel not because they didn't like the design or conditions, but because they were frustrated with the customer service. The importance of internal operations will satisfy all service needs of the customers, customers will be happier even in the face of product problems.

Technology also plays an important role in relationship marketing. The Internet has made it easier for companies to track, store, analyse and then utilize vast amounts of information about customers. Customers are offered personalized ads, special deals, and expedited service as a token of appreciation for their loyalty.

Social media allow business to engage their customers in an informal and growing way. Earlier it would have been impossible to keep useful information about every single customer, but technology makes it easy for companies to automate their marketing efforts. Branding is the final component of relationship marketing. A company can form a long-term relationship with a customer if that customer feels like the brand they purchase reflects who they are or who they want to be. In hospitality 
customers are less inclined to switch to a different brand if they think that switch makes a statement about their identity.

Morgan and Hunt in 1994 propose 'ten relationship exchanges' with 'four partnerships' groups and 'ten relationships': buyer partnerships (ultimate customers, intermediate customers), supplier partnerships (goods suppliers, service providers), lateral partnerships (competitors, non-profit organizations, governments), and internal partnerships (functional departments, employees, business units) (Maxim A., 2009).

One of the most relevant type of marketing that closely connected with relationship marketing is digital marketing. Digital marketing has become one of the most popular directions in the last couple of years. Digital marketing is the way to grow an online business. After typing the phrase 'digital marketing' in Google trends, the statistics will be presented in such way [1]:

Popularity dynamics (?) $\quad$ ๖〈く

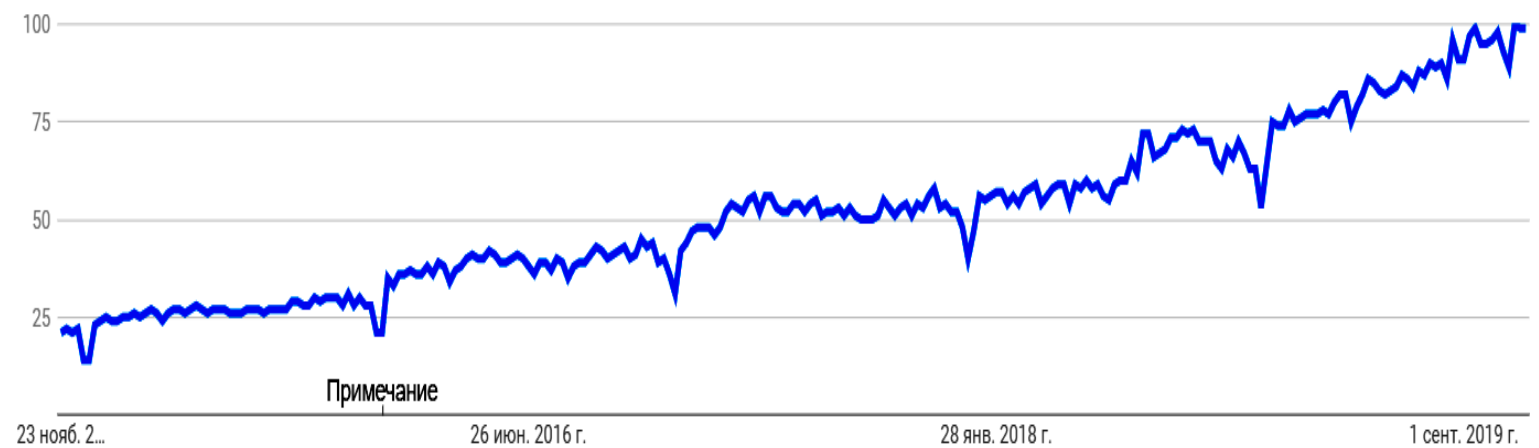

Figure 1. Digital Marketing Search Terms Popularity [1]

Taking into consideration shown above we can conclude that during last 5 years interest in marketing has increased.

Digital marketing is a broad term that includes all marketing channels and methods, which company can use to promote products or services on the Internet but also on electronic devices such as TVs, mobile phones and electronic billboards. The main difference between digital marketing and traditional marketing is that digital marketing campaigns are executed exclusively through digital channels. This gives marketers more control, tools, and data to analyse the effectiveness of a campaign. Digital marketing has a number of channels and these can be separated into online marketing channels and offline marketing channels. The main difference between them is that online marketing channels are based solely on the Internet while offline 
marketing channels have to do with digital devices that are not necessarily connected to the Internet.

\section{Analysis of recent researches and publications.}

One of the most complicated tasks facing any business is getting hold of new customers. When considering that each step is to earn a potential customer's attention, making a persuasive pitch and facilitating the accompanying sale can incur huge expenses. The term used to describe this is relationship marketing.

Many domestic and foreign scholars have dealt with the problem of researching the theoretical aspects of relationship marketing: A. Ardishvili, A. Afanasiev, V. Bagiev, M. Baker, V. Voychak, S. Garkavenko, Y. Gordon, V. Doroshev, F. Kotler, S. Kushch, I. Solovyov, A. Sterlin, D. Rafinezhad, X. Hakansson, O. Yuldasheva, Greenroose, A. Reichheld, M. Sasser.

At the same time, there is no single approach to defining the term «relationship marketing», its essence is ambiguous. There are many definitions of different authors. For example, J. Lamben (2014) presented relationship marketing as a set of practical methods of customer retention. According to K. Granroos (2011) relationship marketing is the result of marketing, which continues to develop and reflects its current state, as the next step after the concept of socially oriented marketing. Also, relationship marketing is a strategy designed to foster customer loyalty, interaction and long-term engagement. It is designed to develop strong connections with customers by providing them with information directly suited to their needs and interests and by promoting open communication (Samanta I., 2009). Thus, relationship marketing is about forming long-term relationships with customers. Rather than trying to encourage a one-time sale, relationship marketing tries to foster customer loyalty by providing exemplary products and services. Relationship marketing involves a company refining the way they do business in order to maximize the value of that relationship for the customer (Payne, Adrian, David B., Martin C., 2005).

\section{Presenting main material.}

The peculiarity of relationship marketing in hospitality is the specific of service. The hotels have achieved success when do everything possible to retain their customers. To gain a place in the modern market, companies in hospitality must focus on the customer - to provide the highest value to their target customers. Competition intensifies, and costs for attracting new customers increase. In addition, customers themselves are becoming more independent and demanding. To stay competitive, a modern company must be well informed about its customers. For this, new business models are developed and innovative solutions are offered. 


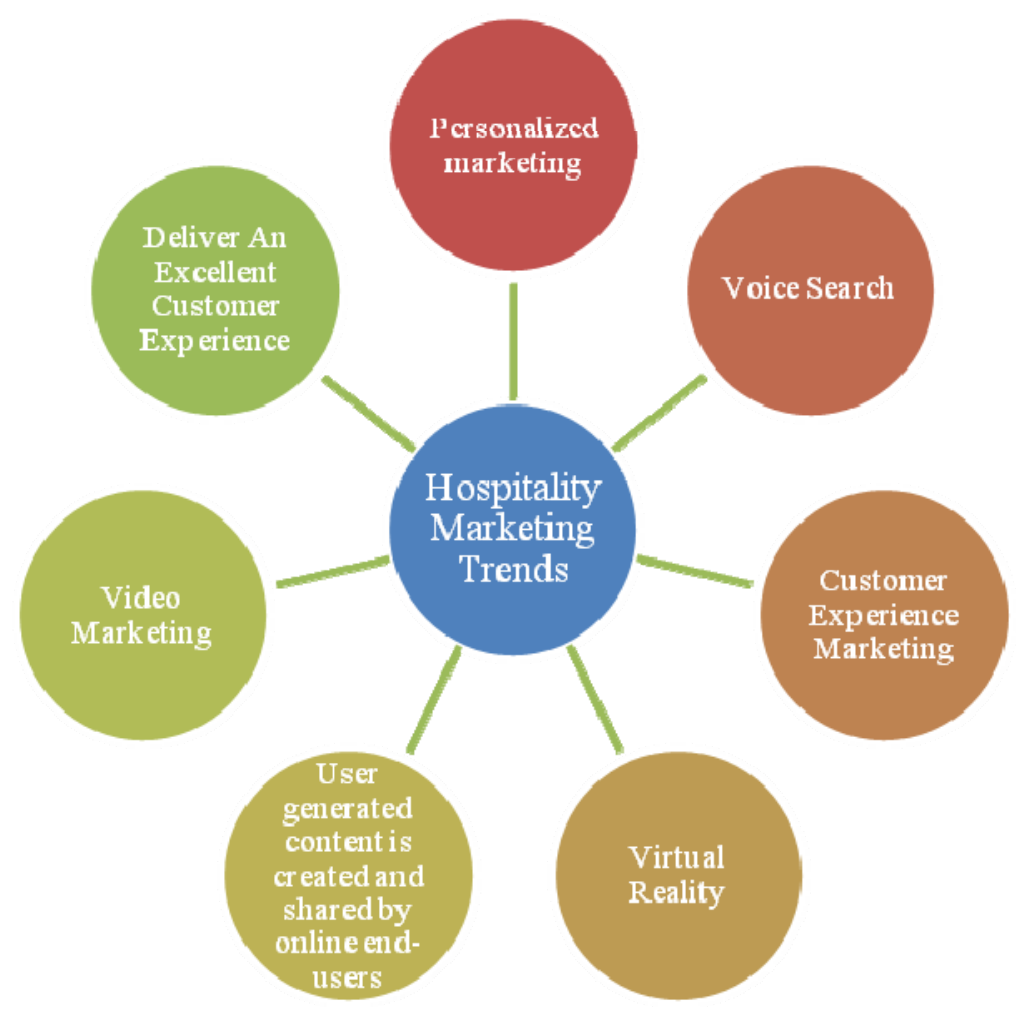

Figure 1 Top 10 Latest Hospitality Marketing Trends [23]

Firstly, personalized marketing allows companies to deliver individualized content to target customers through the use of automation technology and data collection. The goal of personalization marketing is to engage potential customers by communicating with them as individuals. For hotels it's important to personalize their services for their guests and clients through targeted emails and social media. User generated content is created and shared by online end-users. It can come in different forms, such as testimonials, comments, forums, blog posts, and social publications, to name but a few. Hotel have to implement user generated content correctly; company will be able to increase brand awareness significantly.

This strategy will also help to get more room bookings. An effective way to encourage guests to share their experience on social media are hotel contests, creation brand hashtags or photo opportunities at the hotel. Hotels develop social media pages in Google, Facebook and Instagram. Customers read comments also from Booking.com, TripAdvisor and other travel agencies. Very important tool is to respond to guest's reviews. It shows how guest's feedback important for company although good or bad this comment is. Moreover, SMM manager posts Instagram stories and photos about current hotel promotion and news.

Young people take information mainly from Instagram and social media is a good source to influence them. Statistic said: $52 \%$ of people are inspires to travel because of their friend's Facebook photos, $20 \%$ of leisure travellers worldwide look to 
social media for inspiration. For example, targeted emails can be sent to potential customers whenever an upcoming discount is offered by the hotel. Personalization marketing is one of the most direct hospitality marketing strategies to establish a more personal relationship with customers, encourage them to make a return visit and increase customer's lifetime value.

Also travel industries and hotels can use video marketing to engage their target audience from YouTube videos, Instagram, or Snapchat, to going Live on Facebook. Gaining brand exposure and capturing the attention of audience can be done through written content, but in order to engage them instantly, why not give them easily digestible videos about hotel or resort. For example, Holiday Inn can use video marketing to capture the relaxing moments guests can enjoy in hotel's facilities.

Keep in mind that hotel's videos or photos must be very high quality in order to attract customers. The range of options available to marketers is almost endless, from live streams of hotel activities, through to promotional videos highlighting hotel features, and interviews with customers, sharing their experiences. The growing prevalence of 360-degree video also opens up greater opportunities to fully immerse audiences.

Another trend of relationship marketing is voice search. The modern generation of Web users prefer to communicate through voice activation. Voice search is a type of voice control and recognition technology that primarily works with tablets, smartphones, and other similar devices. This marketing trend could soon eliminate the need for Internet users to press buttons or type their search queries online. Hotel guests can book a hotel room via their smartphone by just speaking to the device. There are some elements of control the room's functions, such as lights, music, or heating through voice search.

In the competitive world of hospitality industry, customer experience is essential in gaining loyalty. Providing an excellent customer service at hotels doesn't always result in direct profits. Generation returns and a steady stream of returning customers, compiling analytics from online customer testimonials on review websites provide hotels with a wealth of information about customers' preferences.

The special applications on internal websites and pages in social media give employees an opportunity to see upcoming stay and detailed information about guest preferences. Usually Front desk staff uses this report just to see hotel loyalty members.

At the same time, this is good opportunity to make stay more personalized. The loyalty report shows how many point guests have, his membership number, status, last stay, room rate. Hotel determines what type of traveller guest is - business, leisure. There is information about quantity of stays in certain hotels, last hotel in stay history. Hotel can use this data to make stay more personalized. Hotel could offer discount for 
dinner in the restaurant or free glass of wine/beer to improve relationship marketing. Moreover, it is also a good tool to increase revenue.

When online users look for information on tours and hotels, they can make better decisions through videos and pictures rather than content. This is where virtual reality will have an impact on users' experiences as they can virtually put themselves right there in the hotel room or resort to see whether it meets their needs or not. Virtual reality is not just an entertaining marketing feature, but it also offers endless possibilities. The hospitality industry can use virtual reality to show their customers the local sightseeing attractions. Virtual reality helps take away the guests' or travellers' uncertainty and is an essential tool for all hotel and tour operators to use. For example, Holiday Inn Express Adelaide in Australia has 360 Virtual Tour that shows reception desk, elevators, rooms, breakfast point, conference room, bar and gym. In short, check-in process and all hotel facilities.

Competition is highly fierce in the hospitality industry and using the right marketing tools plays an important role in helping hotel succeed.

\section{Conclusions}

Relationship marketing tools are aimed at ensuring stable relations between the client and the company: development of the product together with the consumer, special types of service, quality guarantees, individual technical requirements, price differentiation, discount systems, bonuses to regular customers, direct deliveries, catalogues, personal contacts, special events, special offers, hotline, marketing events, customer clubs and communications. The 6 market model helps the organization to study about the stakeholders and key market domain that may be important to them Internal, Referral, Influence, Supplier and alliance, Recruitment and Customer markets.

Hotels in Ukraine will have better result if improve hotel relationship marketing. Competitors go beyond and provide better service, better IT technology at the same price. Hospitality market in Ukraine is growing every year, despite political instability and low solvency of citizens. Foreign customer is very demanding guest and hotels are fighting for everyone. In order not to lose position in the market, Hotels in Ukraine need to monitor constantly the changes and trends and implement them as soon as possible.

\section{REFERENCES}

1. Alex Chris «What is Digital Marketing?», 2019. Access code: https://www.reliablesoft.net/what-is-digital-marketing/ 
2. IHG Our Hotels RB2018. - Access code: https://www.ihgplc.com//media/ihg/files/responsible-business/2018-responsible-business/sections/ihg-ourhotels-rb2018.pdf

3. Maxim A. Relationship Marketing - A New Paradigm in Marketing Theory and Practice 2009.-Access code: https://www.researchgate.net/publication/4653273

4. Payne, Adrian, David B., and Martin C. A stakeholder approach to relationship marketing strategy: The development and use of the «six markets» model. European Journal of Marketing 39,2005.-855-871p.

5. Relationship Marketing 2018. - Access code: https://www.marketingschools.org/types-of-marketing/relationship-marketing.html

6. Reichold, F.F. and Sasser, W.E. (1990). «Zero defections: Quality comes to services». Harvard Business Review. (September-October), pp. 105-111

7. Samanta I. The Impact of e-Customer Relationship Marketing in Hotel Industry 2009. Access Code: https://link.springer.com/chapter/10.1007/978-3-64204757-2_52

8. Zeithamal, V.A and Bitner, M.J. (2000). Services Marketing: Integrating Customer Focus Across the Firm. Tata McGraw-Hill Publishing Co. Ltd.

9. Wambugu, M.W. (2002). Factors that determine store loyalty: The case of selected supermarket chains in Nairobi. Unpublished MBA project, UON

10. Webster, F. E. Jnr. (1994). Market Driven Management. New York: John Wiley and Sons, Inc

11. Christian Gronroos (2011) From Marketing Mix to Relationship Marketing: Towards a Paradigm Shift in Marketing. Swedish School of Economics and Business, Administration, Finland Available online 25 October 2011. https://www.sciencedirect.com/sdfe/pdf/download/eid/1-s2.0S1320164694702756/first-page-pdf 